\title{
Greek fisheries and the economic crisis: structural analogies
}

\author{
Athanassios Machias ${ }^{1, *}$, Konstantinos Tsagarakis ${ }^{1}$, Manos Matsaganis ${ }^{2}$ \\ ${ }^{1}$ Hellenic Centre for Marine Research, Institute of Marine Biological Resources and Inland Waters, \\ $46.7 \mathrm{~km}$ Athinon-Souniou Ave., PO Box 712, 19013 Anavyssos, Greece \\ ${ }^{2}$ Athens University of Economics and Business, Patission 76, 10434, Athens, Greece
}

\begin{abstract}
The Greek economic crisis has attracted much attention during recent years, as its depth and duration have been far greater than in crises experienced elsewhere. Structural similarities and peculiarities between the Greek economy and fishery sector are identified in terms of the large number of small enterprises and artisanal vessels, as well as inefficiencies in data collection and tax compliance (unreported income or landings). These highly differentiate Greece from most of the rest of the developed world. In the absence of domestic reforms geared to the specific case of Greece, policy solutions applied elsewhere are being imported into the country, with little success so far. We argue that structural characteristics should be taken into account in order to facilitate economic recovery and improve the efficiency of fisheries.
\end{abstract}

KEY WORDS: Mediterranean Sea $\cdot$ Fisheries management $\cdot$ Data collection $\cdot$ Inaccurate reporting $\cdot$ Economics $\cdot$ Tax evasion

\section{INTRODUCTION}

Fisheries is an activity in which biology, ecology, policy (management), economy and other disciplines are brought together. Tsikliras et al. (2013) described a series of analogies between global crises in fisheries and the wider economy. The authors, among others, used certain countries currently in recession as examples of such analogies. We share this rationale, and we believe that such an approach can provide fresh insights into the management of natural resources. We contribute to this effort by offering additional observations, while simultaneously pointing out the need to confront the issue at the case level. This approach aims to facilitate specific solutions which take into account structural characteristics and local peculiarities and can contribute to overcoming the current impasse. To this end, we provide a brief analysis of relevant aspects of the Greek economic crisis and fisheries management in the country.

*Corresponding author: amachias@hcmr.gr

\section{GREEK ECONOMIC CRISIS AND FISHERIES: GENERAL CONTEXT}

In recent years, the world economy has been in turmoil. The global financial crisis of 2007-2009 was followed by the sovereign debt crisis of 2011-2013, interrupted by a modest recovery in 2009-2011, and revisited by the dramatic Greece-European Union (EU) confrontation in 2015. Several authors have labelled this global crisis the 'Great Recession' (Jenkins et al. 2013), as it affected large areas of the globe, and because its duration and depth exceeded those of previous downturns globally. In Europe, the size of the economy in 2013 was still below its 2008 level (Eurostat 2015).

Greece stands out among the countries worst affected by the global economic crisis, as the depth and duration of the Greek crisis were far greater than those experienced elsewhere. The Greek economy has been in recession for 8 consecutive years (time of

() The authors 2016. Open Access under Creative Commons by Attribution Licence. Use, distribution and reproduction are unrestricted. Authors and original publication must be credited. 
writing April 2016). The latest official figures reveal that the size of the economy has contracted by $26.4 \%$ in real terms relative to 2007 (Eurostat 2015). The loss in output, amounting to a dramatic fall in living standards, has been far greater than the equivalent contraction in other southern European economies (Italy: $-8.5 \%$; Spain: $-6.3 \%$; Portugal: $-8.2 \%$ ) or Ireland $(-6.7 \%)$ over the same period.

What were the causes of the Eurozone crisis in Greece, and how did they differ from those leading to crises in other countries? While this is a politically contested and hotly debated topic, the emerging consensus (Baldwin et al. 2015) has identified macroeconomic imbalances in the Eurozone as being at the root of the crisis. Greece, Portugal, Spain, Italy and Ireland all ran significant current account (i.e. mostly trade) deficits in the years preceding the sovereign debt crisis. However, Greece experienced far greater trouble because it amassed huge fiscal as well as trade deficits. In contrast, in Ireland, Spain and elsewhere, governments had maintained a more sound fiscal position, which deteriorated only when they were forced to bail out the banks threatened with collapse in the context of a housing bubble.

Similarly, Greek fisheries (like those of other Mediterranean countries) present several fundamental differences compared to those of the European Atlantic, associated with (1) distinct environmental conditions, (2) structure of the fishing fleet and consequently (3) composition and volume of catches (e.g. Smith \& Garcia 2014). The Mediterranean Sea is a semi-enclosed, oligotrophic basin compared to the rich adjacent oceanic areas, with a prominent west to east gradient in oligotrophy (Bosc et al. 2004). It supports a very large biodiversity of species $(5.5$ to $7 \%$ of the world's marine fauna; Relini 2003), while large mono-specific fisheries contribute only little to the total landings in contrast to fisheries in the open oceans. Fishery production in the EU's Mediterranean and Black Sea waters is (by weight) $10.5 \%$ of total EU (excluding overseas) fisheries (Eurostat 2013); interestingly, however, the fishing fleets of EU Mediterranean countries are characterized by a relatively large number of vessels. Greek Seas (eastern Ionian, Aegean, Cretan, Libyan and Levantine Seas), located in one of the most oligotrophic regions within the Mediterranean, support the largest fishing fleet among the EU countries in terms of the number of vessels. In this sense, Greek fisheries are similar to the other Mediterranean fisheries but probably represent the most extreme case.

\section{SMALL FIRM SIZE AND SMALL-SCALE FISHING}

Greece stands out among all European countries in terms of exceptionally small firm size. Very small businesses (with 1 to 9 employees) account for $86 \%$ of all non-banking firms, and $27 \%$ of all employment in that sector (with an average of 2.3 employees per company). In addition, self-employed workers with no employees account for approximately $25 \%$ of the total employment in Greece, in comparison to circa $10 \%$ in the EU as a whole. In Italy, the next major country with a large number of own-account workers, the equivalent figure is $16 \%$ (note that these figures do not include 'moonlighting', i.e. employees with a second job in informal self-employment, such as school teachers offering private lessons). On the whole, Greece presents the highest share of 'micro-enterprises', defined as those enterprises employing 0 to 9 workers (i.e. including both very small firms with employees and personal companies of self-employed workers). Indeed, a recent survey showed that in 2012, micro-enterprises in Greece accounted for $96.4 \%$ of all enterprises and $57.6 \%$ of the workforce (ILO 2014).

This is mirrored in Greek fisheries. In spite of low production, the Greek fleet is the largest in the EU, comprising 15165 artisanal vessels (below $24 \mathrm{~m}$ ), dispersed along hundreds of landing sites on the coastline and islands, and 534 semi-industrial ones (middle-sized trawlers and purse-seine vessels; Kavadas et al. 2013). In all, Greece accounts for $20 \%$ of the EU fleet but only $1.3 \%$ of EU fisheries production (Eurostat 2013). In addition, an unknown number of recreational fishing boats and fishers operate with unknown landings (unpublished estimates from the Greek Ministry of Maritime Affairs indicate more than 87000 licences for recreational fishing vessels in 2010). The total impact of the artisanal fleet is considerable. Annual landings in Greece are approximately $24000 \mathrm{t}$ for bottom trawlers, $51000 \mathrm{t}$ for purse seiners (targeting small and medium-sized pelagic fish) and $72000 \mathrm{t}$ for artisanal vessels (using a great variety of gear and targeting numerous species; Anonymous 2008). However, landings per artisanal vessel and income per fisher are both very low. The similarities between Greek fisheries and the wider economy, in terms of the large number of production units of low size and low efficiency, are clear.

\section{INFORMATION DEFICIENCIES}

Successful policies require up-to-date and accurate information, but for structural reasons Greek fish- 
eries and the wider economy both suffer from information deficiencies. Small firm size is intimately linked to unreported income and, eventually, tax evasion. Most undocumented workers tend to be employed in micro enterprises in tourism, construction and domestic work. For instance, the proportion of employees found not to be regularly insured in firms investigated by the Labour Inspectorate has steadily increased in recent years, from $25 \%$ in 2010 to $30 \%$ in 2011 and more than $36 \%$ in 2012 . On the other hand, self-employed workers are known to under-report their income for tax purposes. For example, Matsaganis et al. (2012) found that the proportion of real income not reported by the selfemployed is nearly $40 \%$ (more than $80 \%$ in the case of farmers), while in the case of employees earning wages or salaries it is below $1 \%$. Similarly, Artavanis et al. (2012) estimated that the rate of income underreporting was highest among the so-called 'liberal professions': $55 \%$ in the case of the legal profession, $58 \%$ in the case of engineering and related professions and $59 \%$ in the case of the medical profession.

The tendency of self-employed workers to evade taxes is hardly a Greek phenomenon. In the USA, where tax administration is more efficient (and law enforcement is more strict), the rate of under-reporting of self-employment earnings was estimated to be $58.6 \%$ in 1988 (Slemrod \& Yitzhaki 2002) and $57 \%$ in 2001 (Slemrod 2007), compared to 0.5 and $1 \%$, respectively, in the case of wages or salaries. The key difference is structural: in Greece, as mentioned above, the self-employed account for $25 \%$ of the workforce, while in the USA the equivalent figure is $8 \%$.

In addition, widespread clientelism and favouritism in the public sector contribute to a culture of secrecy, militating against transparency, e.g. via the collection and subsequent release of sound data. For instance, data on the number of public employees only began to be released in July 2010 in Greece, while data on the number of pensioners (as opposed to the number of pensions, given that some pensioners receive more than 1 pension) only began to be known in January 2014. The absence of knowledge and information meant that selected groups could secretly be favoured.

Greek fisheries reflect many of the above features. Public authorities have an insufficient picture of the size, composition and distribution of landings to manage fisheries properly. Greek statistical authorities do not monitor professional vessels smaller than $12 \mathrm{~m}$ (which encompasses approximately 10000 artisanal vessels, i.e. more than half of the fishing fleet), nor the recreational fishery. Nonetheless, an unknown number of professional fishers are not fully active, relying on secondary activities for supplementary income. Moreover, the Greek fishing fleet is dispersed along the extensive coastline (>16 $000 \mathrm{~km})$, any point of which is a potential landing site for the low daily catch of each vessel. Inspection by coastal authorities is very difficult, compliance is low, and policy implementation is inefficient.

Small production by a large number of individuals/vessels results in high levels of unreported landings (an analogy to unreported income). In recent years, it is probable that the size of recreational fisheries has grown further, to compensate for loss of income elsewhere. However, there is no monitoring scheme for the recreational fishery. The most reliable source of information is the fisheries data collection scheme under data collection regulation / data collection framework (DCR/DCF) (EU 2000, 2008), but these EU regulations have only been implemented sporadically (from 2003 to 2006, 2008 and 2014). An important consequence is that the impact of each fleet segment is unknown, and the state of the Greek stocks is not assessed by the relevant bodies (e.g. STECF 2015). This misreporting does not reflect a deliberate effort to mask the situation by reporting false data, as in several other countries (Tsikliras et al. 2013), but nevertheless, the existing situation is not recorded.

\section{POLICIES AND MANAGEMENT}

Early stock assessment methods and fisheries management were mainly developed for large monospecific fisheries of the Atlantic and Pacific Oceans (e.g. see Beverton 1998). Most of the early analyses in Mediterranean fisheries used classic methods. However, neither were the available data always appropriate nor were the methods used always suitable for the multi-gear and multi-species nature of these fisheries (Lleonart \& Maynou 2003). Similarly, management is not adaptive (Lleonart \& Maynou 2003), and policy measures are mainly directed at trawlers and purse seiners, i.e. imitating those applied in Atlantic fisheries. It seems that in a multi-species, multi-gear fishery, policies restricted to these fishing fleet categories are of limited potential; it is impossible to reverse over-exploitation without also giving attention to fleet segments responsible for the majority of landings, and without allocating management measures according to the impact of each fleet on the stocks. Even though fisheries research and data collection have advanced in recent years, management has failed to improve the status of stocks in Greece 
and the Mediterranean (Vasilakopoulos et al. 2014), in contrast to the NE Atlantic, where several successful management plans (e.g. for North Sea herring) have been implemented (Fernandes \& Cook 2013).

This brings to mind the recent application of 'structural reforms' by Greek governments following the sovereign crisis and EU bailout. The failure of policies imposed by the EU-European Central Bank-International Monetary Fund troika to kick-start the Greek economy may be seen as another manifestation of a general pattern. In the absence of a domestically grown reform project, suitable for the specific case of Greece, the attempt to modernise the country was imposed externally, on the basis of reform proposals elaborated in very different national contexts. The polarization of domestic politics between those tacitly accepting vs. those vehemently rejecting the bailout package helped divert attention from the more fundamental matter of the actual content of the reforms needed for Greece to exit the current crisis.

The structure of the Greek economy makes reform difficult. Large numbers of self-employed workers, and a myriad of small firms that are only profitable when they flout regulations, create powerful political constituencies against fighting tax evasion and general law enforcement. Moreover, these constituencies can appeal to the smaller (average) income groups concerned, compared for example with 'oligarchs'. Clearly, fighting illegality in high places is crucial for diffusing a sense that the law is equal for all. Nevertheless, 'oligarchs' are so few and far between, that - from a fiscal point of view - fighting tax evasion among the middle classes (e.g. the liberal professions or small firms) is much more effective in terms of increasing the tax intake (Matsaganis et al. 2012).

As pointed out above, small-scale production and information deficiencies are shared by both Greek fisheries and the wider economy, setting them apart from the fisheries and economy of other European countries. Yet policy solutions, imposed in the context of Greece's bailout (or selected based on fisheries management in the Atlantic) seem more geared to the experience of other economies (and fisheries sectors) than designed for the specific case of Greece. Local solutions, informed by international experience but not attempting to import it wholesale, may be more successful in terms of public acceptance, better enforcement and removing obstacles to modernisation and effective management.

Acknowledgements. We thank 2 anonymous reviewers for their valuable and constructive comments.

\section{LITERATURE CITED}

Anonymous (2008) National Program for the Collection of Fisheries Data (2007-2008). Tech Rep (EC 1543/2000). Fisheries Research Institute and Hellenic Center for Marine Research, Athens

Artavanis NT, Morse A, Tsoutsoura M (2012) Tax evasion across industries: soft credit evidence from Greece. Chicago Booth Res Pap No. 12-25. Booth School of Business, University of Chicago, Chicago, IL

Baldwin $\mathrm{R}$, Beck T, Bénassy-Quéré A, Blanchard O and others (2015) Rebooting the Eurozone: step I - agreeing a crisis narrative. CEPR Policy Insight no. 85. Available at www.voxeu.org/article/ez-crisis-consensus-narrative (accessed April 2016)

Beverton R (1998) Fish, fact and fantasy: a long view. Rev Fish Biol Fish 8:229-249

Bosc E, Bricaud A, Antoine D (2004) Seasonal and interannual variability in algal biomass and primary production in the Mediterranean Sea, as derived from 4 years of SeaWiFS observations. Global Biogeochem Cycles 18, GB1005, doi:10.1029/2003GB002034

EU (European Union) (2000) Council Regulation (EC) No. $1543 / 2000$ establishing a community framework for the collection and management of the data needed to conduct the common fisheries policy. Off J Eur Communities L176:1-16

EU (2008) Council Regulation (EC) No. 199/2008 concerning the establishment of a community framework for the collection, management and use of data in the fisheries and support for scientific advice regarding the Common Fisheries Policy. Off J Eur Union L60:1-12

Eurostat (2013) Agriculture, forestry and fishery statistics 2013 edition. Main results-2009-10, ISSN 1977-2262. Publications Office of the European Union, Luxembourg

Eurostat (2015) GDP and main components (output, expenditure and income) [nama_10_gdp] online database. Available at http://ec.europa.eu/eurostat/en/web/products-datasets/-/NAMA_10_GDP (accessed Nov 2015)

Fernandes PG, Cook RM (2013) Reversal of fish stock decline in the Northeast Atlantic. Curr Biol 23:1432-1437

ILO (International Labour Office) (2014) Productive jobs for Greece. International Labour Office, Geneva

Jenkins SP, Brandolini A, Micklewright J, Nolan B (eds) (2013) The Great Recession and the distribution of household income. Oxford University Press, Oxford

Kavadas S, Damalas D, Georgakarakos C, Maravelias CD, Tserpes G, Papaconstantinou C, Bazigos G (2013) IMASFish: integrated management system to support the sustainability of Greek fishery resources. A multidisciplinary web-based database management system: implementation, capabilities, utilization and future prospects for fisheries stakeholders. Mediterr Mar Sci 14:109-118

> Lleonart J, Maynou F (2003) Fish stock assessments in the Mediterranean: state of the art. Sci Mar 67:37-49

Matsaganis M, Leventi C, Flevotomou M (2012) The crisis and tax evasion in Greece: What are the distributional implications? CESifo Forum 13:26-32

Relini G (2003) Fishery and aquaculture relationship in the Mediterranean: present and future. Mediterr Mar Sci 4: 125-154

Slemrod J (2007) Cheating ourselves: the economics of tax evasion. J Econ Perspect 21:25-48

Slemrod J, Yitzhaki S (2002) Tax avoidance, evasion, and 
administration. In: Auerbach AJ, Feldstein M (eds) Handbook of public economics. Elsevier, Amsterdam, p 1423-1470

Smith ADM, Garcia SM (2014) Fishery management: contrasts in the Mediterranean and the Atlantic. Curr Biol 24:R810-R812

STECF (Scientific, Technical and Economic Committee for Fisheries) (2015) Mediterranean Assessments part 2

Editorial responsibility: Konstantinos Stergiou, Thessaloniki, Greece
(STECF-15-06). EUR 27221 EN, JRC 95822. Publications Office of the European Union, Luxembourg

Tsikliras AC, Sumaila UR, Stergiou KI (2013) Parallels in economic and ecosystem crises. Ethics Sci Environ Polit 13:23-25

Vasilakopoulos P, Maravelias CD, Tserpes G (2014) The alarming decline of Mediterranean fish stocks. Curr Biol 24:1643-1648

Submitted: February 16, 2016; Accepted: May 10, 2016

Proofs received from author(s): June 22, 2016 